\title{
ESTIMASI KARBON TERSIMPAN DI ATAS PERMUKAAN TANAH (ABOVE GROUND) DI KAWASAN MEMPAWAH MANGROVE PARK KABUPATEN MEMPAWAH
}

\author{
(Estimation of carbon storage on above ground in Mempawah Mangrove Area of Mempawah \\ regency)
}

\author{
Satri Lestari, Iswan Dewantara, Gusti Hardiansyah \\ Fakultas Kehutanan Universitas Tanjungpura Pontianak, Jl. Daya Nasional Pontianak 78124 \\ E-mail : satrilestari30@gmail.com
}

\begin{abstract}
This study aims to estimate carbon stored in above ground at the Mempawah Mangrove Park (MMP) area of Mempawah District, the data used were mangrove planted in 2013. Full Enumeration was used in this study while collecting the data applied non destructive sampling method for the tree, its was a diameter of $\geq 5 \mathrm{~cm}$. Based on the results of measurements and observations in the field directly, it had 63 of the total number of line which were done by all the areas of Mempawah Mangrove Park in Mempawah District. The result of this study reveals which has 2 (two) kinds of mangrove. They are Avicennia marina dan Rhizopora stylosa. Avicennia marina is kinds of mangrove that dominate with the total number of 35 individuals based on the tree level and 1404 individuals relating the stake level. Then, Rhizopora stylosa gets the stake level for two individuals so that the stand density is 379.21 /ha. The value of biomass in the MMP area is 7.16 tons C/ ha and the carbon value in the MMP area is 3.37 tons C/ha.
\end{abstract}

Keywords: Above Ground Biomass, Carbon, Mangrove Forests

\section{Abstrak}

Penelitian ini bertujuan untuk menduga karbon tersimpan di atas permukaan tanah di kawasan Mempawah Mangrove Park (MMP) Kabupaten Mempawah, data yang digunakan yaitu data yang ditanam pada tahun 2013. Metode yang digunakan pada penelitian ini yaitu pengamatan secara menyeluruh (full enumeration), sedangkan untuk mengumpulkan data di lapangan menggunakan metode non destructive sampling (pengukuran tanpa melakukan pemanenan) pada pohon yang berdiameter $>5 \mathrm{~cm}$. Berdasarkan hasil dari pengukuran dan pengamatan secara langsung di lapangan dengan jumlah jalur sebanyak 63 yang dilakukan pada seluruh kawasan MMP. Hasil penelitian menunjukkan bahwa terdapat dua jenis mangrove yaitu jenis Avicennia mariana dan Rhizopora stylosa yang mendominasi pada kawasan MMP, dimana A. Mariana merupakan jenis yang mendominasi dengan jumlah 35 individu pada tingkat pohon dan 1.404 individu pada tingkat pancang, sedangkan untuk jenis $R$. Stylosa hanya terdapat pada tingkat pancang dengan jumlah 2 individu sehingga didapatlah kerapatan tegakan sebesar 379,21 ind/Ha. Nilai biomassa pada kawasan MMP sebesar 7,16 ton C/Ha dan nilai karbon pada kawasan MMP sebesar 3,37 ton C/Ha.

Kata kunci : mangrove, Karbon, karbon tersimpan

\section{PENDAHULUAN}

Mangrove adalah tumbuhan yang sangat unik karena berada di muara sungai, daerah pesisir pantai dan daerah yang digenangi air berkadar garam tinggi. Secara umum mangrove yang tersebar 
hanya terbatas di daerah subtropis dan tropis. Mangrove memiliki fungsi yang sangat banyak yaitu membantu perekonomian masyarakat yang berada disekitarnya juga sebagai penyedia jasa lingkungan (Badan Informasi Geospasial, 2014).

Di indonesia perkiraan luas mangrove yaitu seluas 3,5 juta hektar, indonesia merupakan tempat mangrove terluas di dunia (18-23\%). Mangrove dapat dijumpai di semua kepulauan Indonesia, daerah mangrove yang paling luas dapat ditemukan di Irian Jaya sekitar 1.350.600 ha (38\%), Kalimantan 978.200 ha (28\%) dan Sumatera 673.300 ha (19\%). Di setiap daerah di Indonesia, mangrove sangat baik tumbuh pada pantai yang mempunyai sungai besar dan terlindung. Meskipun mangrove dapat hidup di wilayah lain di pesisir, perkembangan yang paling cepat di daerah tersebut (Noor et al, 2006). Luas hutan mangrove di Kalimantan Barat sampai dengan tahun 2011 adalah 113.857, $1 \mathrm{Ha}$ (Hardiansyah et al, 2014).

Menurut Bismark et al. (2008) kawasan hutan mangrove memiliki beberapa fungsi yaitu fungsi biologi antara lain hutan mangrove dapat berfungsi untuk memenuhi kebutuhan manusia dalam hal makanan terutama, udang, ikan, kepiting dan kerang, serta untuk kehidupan makhluk hidup yang berada di pantai seperti nekton, algae, dan plankton, kawasan hutan mangrove juga berfungsi secara fisik yaitu sebagai penahan abrasi pantai. Ekosistem hutan mangrove memiliki peran sebagai penyerap $\mathrm{CO}_{2}$ dari udara sehingga sangat relevan untuk mitigasi perubahan iklim. Keberadaan hutan mangrove sebagai penyerap dan penyimpan karbon, melalui proses fotosintesis mengubah karbon anorganik $\left(\mathrm{CO}_{2}\right)$ menjadi karbon organik di dalam tegakan. Bahan tersebut membusuk dan akan melepaskan karbon kembali ke atmosfir berupa $\mathrm{CO}_{2}$ di dalam ekosistem. Sementara hutan mangrove mempunyai kandungan bahan organik yang tidak membusuk dan mampu berfungsi sebagai penyerap dan penyimpan karbon.

Kontributor pemanasan global terbesar adalah karbon dioksida $\left(\mathrm{CO}_{2}\right)$ dan metana $\left(\mathrm{CH}_{4}\right)$ yang diperoleh dari pertanian dan peternakan, nitrogen oksida (NO) dari pupuk, dan gas-gas yang digunakan untuk kulkas dan pendingin ruangan (CFC) (Imiliyana et al, 2014).

Hutan alam berfungsi sebagai ekosistem penyimpan karbon tertinggi dibandingkan dengan system penggunaan lahan (SPL) pertanian sebagai akibat adanya keragaman pohon yang tinggi (Hairiah da Rahayu, 2007). Hutan mangrove merupakan ekosistem hutan yang berfungsi sebagai penyimpan karbon tertinggi pada daerah tropis dan berguna dalam mengurangi kadar $\mathrm{CO}_{2}$ di udara (Hartoko et al. 2013). Pelestarian hutan mangrove sangat penting dilakukan karena mangrove menyerap $\mathrm{CO}_{2}$ dan mengubahnya menjadi karbon organik yang disimpan pada akar, batang, daun, ataupun bagian lainnya (Hairiah dan Rahayu, 2007).

Mempawah Mangrove Park (MMP) Kabupaten Mempawah merupakan tempat wisata yang diminati oleh masyarakat, baik oleh masyarakat Kabupaten Mempawah maupun masyarakat yang berada diluar Kabupaten Mempawah karena keindahannya dan juga sebagai 
tempat edukasi masyarakat untuk menambah wawasan mengenai tumbuhan, terutama mangrove, MMP memiliki hutan mangrove yang berpotensi menyerap gas $\mathrm{CO}_{2}$ di atmosfer sebagai upaya untuk mengurangi efek rumah kaca di udara, namun sampai saat ini besarnya simpanan karbon pada pohon mangrove di MMP masih belum diketahui sehingga perlu adanya penelitian untuk mengetahui estimasi karbon tersimpan di atas permukaan tanah (above ground) pada pohon mangrove di MMP.

Penelitian ini bertujuan untuk mengevaluasi manfaat ekologi hutan mangrove dalam rangka penyimpanan karbon sekalgus ebagai upaya konsevasi mangrove untuk mengurangi pemanasan global.

\section{METODE PENELITIAN}

Penelitian ini dilakukan di Mempawah Mangrove Park Kabupaten Mempawah dengan luas kawasan sebesar 3,8 Ha. Penelitian ini dilakukan dilapangan selama 1 bulan. Metode yang digunakan pada penelitian ini yaitu pengamatan secara menyeluruh (full enumeration). Jalur pada penelitian ini dibuat dengan lebar $10 \mathrm{~m}$ dimulai dari tepi pantai dan panjangnya disesuaikan pada kondisi dilapangan hingga mencapai batas mangrove dan dilakukan pada seluruh kawasan MMP. Kemudian dilakukan penitikan pada setiap jalur menggunakan GPS. Sedangkan untuk pengumpulan data dilapangan menggunakan metode non destructive sampling (pengukuran tanpa melakukan pemanenan), yaitu pengumpulan data dilapangan yang dilakukan dengan cara mencatat seluruh jenis pohon (pohon dengan diameter $\geq 5$ $\mathrm{cm})$, jumlah pohon, dan mengukur diameter batang. Pengukuran diameter batang setinggi dada $(\mathrm{DBH}=$ diameter $a t$ breast height) atau 1,3 meter diatas permukaan tanah dilakukan dengan menggunakan pita ukur dan tongkat kayu ukuran panjang 1,3 m pada seluruh areal pengamatan. Contoh kondisi di lapangan dapat dilihat pada Gambar 1.

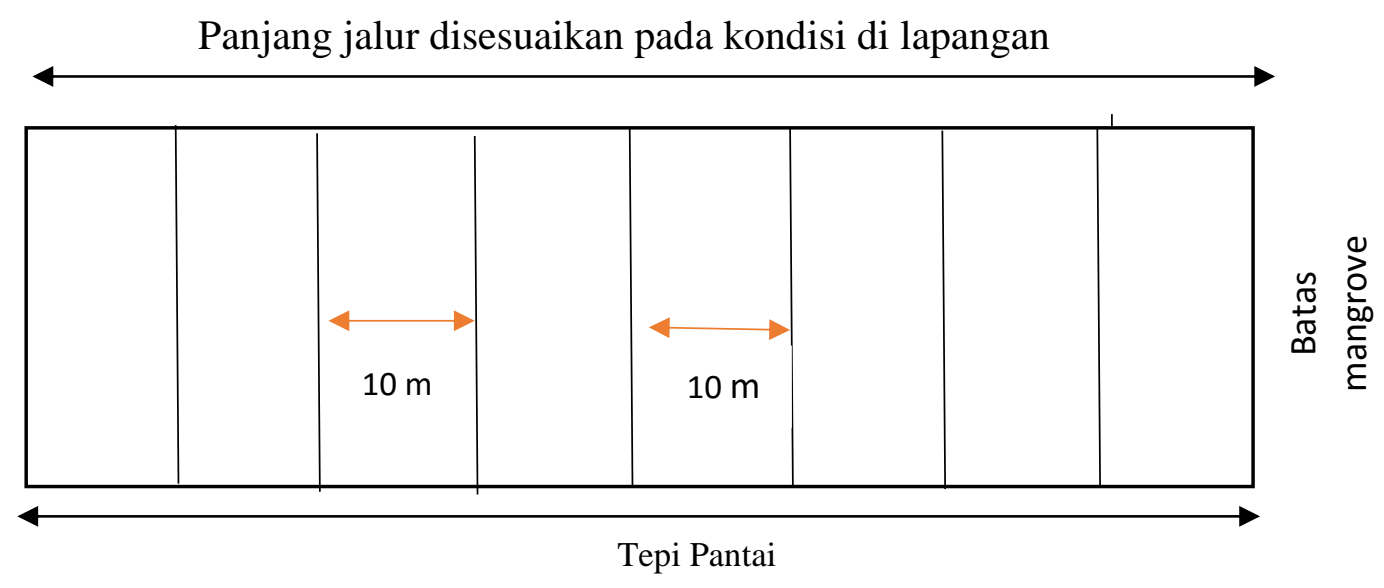

Gambar 1. Desain petak contoh di lapangan dengan metode full enumeration

Data hasil penelitian ini berupa dengan menggunakan persamaan diameter dan jenis pohon, selanjutnya allometrik seperti tercantum pada Tabel dianalisa untuk mengetahui biomassa 1 . 
JURNAL TENGKAWANG (2020)

Vol. 10 (1) : 1 - 10

Tabel 1. Rumus Penghitungan Allometrik Biomassa (Biomass allometric calculation formula)

\begin{tabular}{llll}
\hline Jenis tanaman & Persamaan allometrik & $P$ & Sumber \\
\hline Avicennia marina. & Wtop $=0.308 \mathrm{DBH}^{2.11}$ & - & Comley and McGuinness (2005)
\end{tabular}

Rhizopora spp Wtop $=0.235 D B H^{2.42} \quad$ - $\quad$ Ong et al (2004) dalam Badan

Dimana:

Wtop = Biomassa atas permukaan

DBH = diameter pohon setinggi dada (1,3 $\mathrm{m}$ dari permukaan tanah)

Setelah diketahui nilai biomasanya kemudian dilakukan penghitungan nilai karbon tersimpan menggunakan rumus (SNI 7724:2011) sebagai berikut:

\section{$\mathrm{Cb}=\mathrm{B} \times \% \mathrm{C}$ organik}

\section{Keterangan:}

$\mathrm{Cb} \quad=$ Kandungan karbon dari biomassa, dinyatakan dalam kilogram $(\mathrm{kg})$;

B = Total biomassa pohon dinyatakan dalam $(\mathrm{kg})$;

$\% \mathrm{C}$ organik = Nilai persentase kandungan karbon, sebesar 0,47 atau menggunakan nilai persen karbon yang diperoleh dari hasil pengukuran di laboratorium.

\section{HASIL DAN PEMBAHASAN}

Mempawah Mangrove Park merupakan merupakan objek wisata yang didirikan pada tanggal 23 Agustus 2016, Objek wisata ini terdapat di Desa Pasir Kecamatan Mempawah Hilir Kabupaten Mempawah Provinsi
Kalimantan Barat. Awalnya hanya pantai berlumpur yang berada disepanjang pesisir Desa Pasir, tetapi kini telah berubah hijau ditumbuhi aneka jenis tumbuhan penahan abrasi yang dikelola oleh Mempawah Mangrove Conservation dan masyarakat dengan luas lokasi 3,8 ha.

\section{Kerapatan Tegakan}

Berdasarkan hasil dari pengukuran dan pengamatan secara langsung dilapangan yang dilakukan dengan menggunakan metode full enumerasion (pengamatan secara menyeluruh di lapangan) dengan jumlah sebanyak 63 jalur yang dilakukan pada seluruh kawasan MMP maka didapatlah dua jenis mangrove dengan jumlah individu pohon yang berdiameter $\geq 5 \mathrm{~cm}$ diarea MMP disajikan dengan lengkap pada Tabel 2.

Tabel 2. Jumlah pohon yang ditemukan di lapangan (The number of trees found in the field)

\begin{tabular}{|c|c|c|c|c|}
\hline \multirow[t]{2}{*}{ Jenis pohon } & \multicolumn{2}{|c|}{ Jumlah individu } & \multirow{2}{*}{$\begin{array}{l}\text { Total Individu } \\
\text { (N) }\end{array}$} & \multirow{2}{*}{$\begin{array}{l}\text { Kerapatan } \\
\text { (N/ha) }\end{array}$} \\
\hline & Pancang & pohon & & \\
\hline Avicennia marina & 1404 & 35 & \multirow{3}{*}{1441} & \multirow{3}{*}{379,21} \\
\hline & & & & \\
\hline Rhizopora stylosa & 2 & 0 & & \\
\hline
\end{tabular}


Total keseluruhan pohon yang berjumlah 1441 individu yang ditemui di MMP dengan luas kawasan 3,8 ha terdapat dua jenis pohon yang berdiameter $\geq 5 \mathrm{~cm}$ yaitu A. marina dan R. stylosa. Dimana $A$. marina merupakan jenis yang mendominasi dengan jumlah 35 individu pada tingkat pohon dan 1404 individu pada tingkat pancang, sedangkan untuk jenis $R$. stylosa hanya terdapat pada tingkat pancang dengan jumlah 2 individu sehingga didapatlah kerapatan tegakan sebesar 379,21 ind/ha.

Kerapatan adalah jumlah individu suatu jenis tumbuhan dalam luasan tertentu (Khairijon et al, 2013). Tinggi rendahnya kerapatan tegakan dalam suatu kawasan menunjukan tingkat kepadatan tegakan di kawasan tersebut. Keputusan Menteri Negara Lingkungan Hidup (2004) mengklasifikasikan kriteria kerapatan mangrove yaitu sebagai berikut a) kerapatan $\geq 1500$ pohon/ha tergolong sangat padat, b) kerapatan $\geq 1000$ sampai dengan <1500 tergolong padat, dan c) kerapatan <1000 tergolong jarang. Berdasarkan hal tersebut, maka tingkat kerapatan mangrove di MMP tergolong jarang (379,21 ind/ha). Hal ini dikarenakan kawasan MMP mulanya merupakan kawasan abrasi yang pada bulan maret 2013 dilakukan upaya konservasi oleh masyarakat setempat bersama Kebun Bibit Rakyat (KBR) Sylva Lestari, sehingga belum banyak tegakan yang memiliki diameter $\geq 5 \mathrm{~cm}$. Selain itu, tegakan yang berdiameter $\geq 5 \mathrm{~cm}$ di dominasi oleh jenis A. marina dimana jenis ini merupakan tumbuhan pendatang yang mudah beradaptasi sehingga mulai mendominasi mengalahkan jenis $R$. stylosa yang memang sudah lama di tanam oleh pihak MMP. Menurut Halidah (2014), A. marina merupakan salah satu jenis mangrove dalam katagori mayor hal ini menunjukan bahwa A. marina selalu ada dalam ekosistem mangrove. A. marina juga mempunyai sifat toleran terhadap salinitas tinggi dan mempunyai kemampuan tumbuh pada berbagai habitat pada daerah pasang surut.

Hal ini mungkin diakibatkan dari peletakan penanaman jenis $R$. stylosa di zona yang salah. Menurut Suryono (2013), hutan mangrove mempunyai area tumbuh tertentu dimulai dari bagian yang ditumbuhi pohon pionir dan daerah yang bersalinitas tinggi dan. Dari belakang ke depan area tumbuh mangrove antara lain: (1) area kering dan nipa pada area ini kadar garam airnya sangat rendah dan tanahnya keras serta kurang dipengaruhi oleh pasang surut air laut. (2) area Bruguiera dengan kadar garam airnya sedang, (3) area Rhizophora, (mangemange) kebanyakan didominasi dengan tanaman bakau Rhizophora spp. Pada beberapa tempat bergabung dengan jenis Bruguiera sp (tongke) (4) area yang paling depan yakni: tumbuhan Avicennia spp, area ini menghadapi ombak, air berkadar garam tinggi dengan tanah berlumpur agak lembek.

Pada kawasan MMP penanaman jenis R. stylosa diletakkan mulai dari zona paling depan dimana jenis $R$. stylosa kurang mampu menghadapi ombak yang besar, tanah berlumpur agak lembek dengan salinitas tinggi dibanding jenis Avicennia marina sehingga beberapa jenis $R$. stylosa hasil penanamannya tumbang 
dan mati kemudian terganti dengan jenis A. marina.

\section{Kandungan Biomassa}

Data biomassa mangrove diperoleh berdasarkan pengukuran DBH (Diameter at Breast Height) pohon dan kemudian data tersebut dimasukkan dalam persamaan allometrik pada setiap jenis (Ati et al. 2014). Pengukuran biomassa dilakukan hanya pada pohon yang berdiameter $\geq 5 \mathrm{~cm}$ dengan pengamatan secara menyeluruh (full enumeration) menggunakan jalur sebnyak 63 jalur. Jalur dibuat dengan lebar $10 \mathrm{~m}$ (dimulai dari tepi pantai) dengan panjang yang disesuaikan pada kondisi dilapangan hingga mencapai batas mangrove. Hasil rekapitulasi biomassa tersaji dengan lengkap pada Tabel 3.

\section{Tabel 3. Kandungan Biomassa (Biomass content)}

\begin{tabular}{lcccc}
\hline Jenis Pohon & \multicolumn{2}{c}{ Biomassa (ton C ) } & \multicolumn{2}{c}{$\begin{array}{c}\text { Jumlah Kandungan Biomassa } \\
\text { (ton C) }\end{array}$} \\
\cline { 2 - 5 } & Tingkat Pancang & Tingkat Pohon & 3,8 ha & Rata-rata/ha \\
\hline Avicennia marina & 25,58 & 1,60 & 27,18 & 7,15 \\
Rhizopora stylosa & 0,04 & - & 0,04 & 0,01 \\
\hline Total & 25,62 & 1,60 & 27,22 & 7,16 \\
\hline
\end{tabular}

Sumber : Analisis Data, 2018

Tabel diatas dapat diketahui bahwa pada jenis $A$. marina menyimpan biomassa sebesar 27,18 ton dan rata-rata kandungan biomassa sebesar 7,15 ton/ha dengan tingkat pancang sebesar 25,58 ton dan pada tingkat pohon sebesar 1,60 ton. Sedangkan pada jenis pohon $R$. stylosa menyimpan biomassa sebesar 0,04 ton yang hanya ditemukan pada tingkat pancang dengan rata-rata kandungan biomassa sebesar 0,01 ton/ha. Maka total biomassa yang ditemukan yaitu sebesar 27,22 ton dengan rata-rata sebesar 7,16 ton/ha.

Selisih perbedaan kandungan biomassa pada kedua jenis mangrove tersebut yaitu 27,14 ton/ha. Perbedaan kandungan biomassa ini terjadi karena jenis A. marina merupakan jenis yang mendominasi di area MMP dan ditemukan pada tingkat pancang dan pohon dengan jumlah yang lebih banyak jika dibandingkan dengan jenis $R$. stylosa.
Selain itu, pada jenis $R$. stylosa hanya ditemukan pada tingkat pancang dimana diameter suatu tegakan mempengaruhi besar kecilnya suatu tegakan tersebut menyimpan biomassa. Semakin besar diameter suatu pohon, biomasa yang terkandung pada pohon tersebut semakin besar (Mandari et al. 2016).

\section{Kandungan Karbon Tersimpan}

Salah satu unsur utama pembentuk bahan organik adalah karbon, hampir dari sebagian makhluk hidup merupakan karbon. Maka dari itu jika dibandingkan di atmosfir karbon secara alami lebih banyak tersimpan di bumi (Manuri et al. 2011). Penghitungan nilai karbon tersimpan dilakukan menurut (SNI 7724:2011) yaitu kandungan karbon dari biomassa dikalikan dengan 0,47 atau menggunakan nilai persen karbon yang diperoleh dari hasil pengukuran di laboratorium. Sehingga diperoleh hasil yang dapat dilihat pada Tabel 4. 
JURNAL TENGKAWANG (2020)

Vol. 10 (1) : 1 - 10

Tabel 4. Kandungan karbon tersimpan (Stored carbon content)

\begin{tabular}{ccc}
\hline & \multicolumn{2}{c}{ Jumlah karbon tersimpan (ton C) } \\
\cline { 2 - 3 } Jenis pohon & 3,8 ha & Rata-rata/ha \\
\hline Avicennia marina & 12,77 & 3,36 \\
Rhizopora stylosa & 0,02 & 0,005 \\
\hline Total & 12,79 & 3,37 \\
\hline
\end{tabular}

Sumber : Analisis Data, 2018

Kandungan karbon tersimpan di

pohon mempengaruhi besarnya karbon. kawasan MMP pada jenis A. marina sebesar 12,77 ton $\mathrm{C}$ dan jenis $R$. stylosa sebesar 0,02 ton $C$. Sehingga didapatlah total nilai karbon tersimpan pada areal MMP yaitu sebesar 12,79 ton $\mathrm{C}$ dengan rata-rata kandungan karbon tersimpan sebesar 3,37 ton $\mathrm{C} / \mathrm{ha}$.

Intensitas karbon terbanyak terdapat pada jalur 4 sedangkan yang terkecil ada di beberapa jalur. Jalur 4 terdapat karbon terbanyak hal ini diakibatkan karena jalur tersebut mempunyai jumlah pohon yang banyak serta diameter yang besar, dimana jumlah pohon dan besarnya diameter Sedangkan karbon terkecil terdapat pada 6 jalur yaitu pada jalur 24, 59, 60, 61, 62, 63 dengan besar karbon $0 \mathrm{~kg} \mathrm{C}$. Hal ini diakibatkan karena pada keenam jalur tersebut sama sekali tidak ditemukan keberadaan pohon yang berdiameter $\geq 5 \mathrm{~cm}$ dan hanya terdapat pohon yang kecil-kecil $(<5 \mathrm{~cm})$.

Hasil pengamatan yang telah dilakukan penulis dapat dibandingkan dengan penelitian yang telah dilakukan oleh Wiarta et al. (2017). Adapun perbandingan hasil penelitian yang dilakukan oleh penulis dapat dilihat pada Tabel 5.

Tabel 5. Karbon Tersimpan Berdasarkan Umur Tanaman (Stored content based on plant age)

\begin{tabular}{ccc}
\hline Umur & Karbon Tersimpan (ton C/ha) & Sumber \\
\hline 1 & 1,26 & Wiarta et al. $(2017)$. \\
3 & 6,47 & Wiarta et al. $(2017)$. \\
4,3 & 3,37 & Hasil Penelitian \\
5 & 10,55 & Wiarta et al. (2017). \\
\hline
\end{tabular}

Tabel 5 menunjukan perbandingan hasil penelitian ini dengan penelitian yang dilakukan oleh Wiarta et al. (2017) pada jenis tanaman bakau dengan metode purposive sampling yaitu tanaman berumur 1, 3, 5 tahun dan hasil yang diperoleh oleh penulis, berumur 4,3 tahun terlihat bahwa selisih hasil antara umur 3 tahun dan umur 4,3 tahun sebesar 3,31 ton $\mathrm{C} / \mathrm{ha}$, dan selisih hasil antara umur 4,3 tahun dan umur 5 tahun sebesar 7,18 ton $\mathrm{C} /$ ha. Hasil yang diperole oleh penulis lebih kecil bila dibandingkan dengan hasil Penelitian Wiarta et al. (2017)

Menurut Mansur dan Tuhteru (2010) umur pohon merupakan salah satu faktor yang menyerap karbon lebih banyak jika dibandingkan dengan fase tiang, pancang dan semai, karena semakin tua umur pohon maka semakin besar diameter dan tinggi pohon 
tersebut. Diameter pohon yang besar dapat menyimpan karbon lebih banyak karena batang merupakan kontribusi utama biomassa. Menurut Cahyaningrum et al. (2014) batang adalah tempat untuk menyimpan cadangan makanan dari hasil fotosintesis dan merupakan bagian berkayu, pohon menyerap karbon dari lingkungan dengan melakukan proses fotosintesis, karbon diserap melalui daun, kemudian melakukan fotosintesis, dan disebarkan kebagian pohon yang lain hasil dari fotosintesis tersebut. Bagian terbesar pohon yang mampu menyimpan lebih banyak karbon adalah batang.

Pertumbuhan biomassa hutan secara alami dapat ditingkatkan dengan melakukan peningkatan penyerapan cadangan karbon, penanaman pohon dan mengurangi pemanenan kayu merupakan cara untuk meningkatkan cadangan kayu di hutan serta menanam jenis yang cepat tumbuh dapat memperbanyak pohon hutan. (Suryandari et al. 2019).

\section{KESIMPULAN DAN SARAN}

Berdasarkan hasil penelitian dapat disimpulkan bahwa pada kawasan MMP ditemukan dua jenis mangrove, yaitu Avicennia marina dan Rhizopora stylosa, pada jenis Avicennia marina ditemukan pada tingkat pancang sebanyak 1404 individu dan tingkat pohon sebanyak 35 individu, sedangkan pada jenis Rhizopora stylosa hanya ditemukan pada tingkat pancang sebanyak 2 individu dengan kerapatan tegakan yang jarang yaitu sebesar 379,21 ind/ha. Biomassa pada kawasan
MMP tergolong rendah yaitu sebesar 7,16 ton/ha Kandungan karbon tersimpan tergolong rendah, yaitu sebesar 3,37 ton $\mathrm{C} / \mathrm{ha}$.

Saran untuk penelitian ini yaitu berdasarkan nilai biomassa dan karbon yang dihasilkan, menunjukan bahwa kemampuan ekosistem mangrove dalam menyimpan karbon di kawasan MMP tergolong rendah. Maka dari itu semoga dengan hasil penelitian ini dapat memotivasi masyarakat untuk lebih banyak melakukan penanaman dan menjaga hutan mangrove terutama di kawasan MMP agar lebih banyak menyimpan karbon sebagai upaya untuk mengurangi gas $\mathrm{CO}_{2}$ diudara. Perlu adanya penelitian lanjutan untuk mengetahui karbon yang terdapat pada tumbuhan bawah, kayu mati, dan bahan organik tanah sehingga didapatlah informasi yang lengkap mengenai karbon tersimpan yang terdapat pada kawasan MMP tersebut.

\section{DAFTAR PUSTAKA}

Anonim, 2011, SNI 7724-2011: Pengukuran dan Penghitungan Cadangan Karbon -Pengukuran Lapangan untuk Penaksiran Cadangan Karbon Hutan (Ground Based Forest Carbon Accounting). Badan Standarisasi Nasional. Jakarta.

Ati, R. N. A, Rustam, A., Kepel, T. L., Sudirman, N., Astrid M., Daulat A., Mangindaan P., Salim, H. L, Hutahean, A. A., 2014, Stok Karbon dan Struktur Komunitas Mangrove Sebagai Blue Carbon Di Tanjung Lesung, Banten. Jurnal Segara. No.10 (2) : 119127. 
Badan Informasi Geospasial Nomor 3, 2014, Pengumpulan dan Pengolahan Data Geospasial Mangrove. Lampiran Peraturan Kepala Badan Informasi Geospasial Cibinong.

Bismark, M., Subiandono, E., Heriyanto, N. M., 2008, Keragaman Dan Potensi Jenis Serta Kandungan Karbon Hutan Mangrove Di Sungai Subelen Siberut, Sumatera Barat. Jurnal Penelitian Hutan dan Konservasi Alam (3) : 297-306.

Cahyaningrum, S. T., Hartoko, A., Suryanti, 2014, Biomassa Karbon Mangrove pada Kawasan Mangrove Pulau Kemujan Taman Nasional Karimunjawa. Jurnal Management Of Aquatic Resources. 3 (3) : 34-42.

Comley, B.W.T, McGuinness, K.A, 2005, Above and Below Ground Biomass, and Allometry Of Four Common Northern Australian Mangrover. Aust. Journal Bot. 53, 431-436.

Halidah, 2014, Avicennia Marina (Forssk.) Vierh Jenis Mangrove Yang Kaya Manfaat. Balai Penelitian Kehutanan Makassar. 11 (1) : 37-44.

Hairiah, K., dan Rahayu, S., 2007, Pengukuran 'karbon tersimpan' di berbagai macam penggunaan lahan. Bogor. World Agroforestry Centre.

Hardiansyah, G., Yani, A., Jamani, R., Fahrizal, Erianto, Yuslinda, Jeno, M., Ngo, L. Y., Manuputty, B. D. R., Darmawel, Yenny, Sari, S. E., Rosadi, Haryono, Z., Iskandar, Idham, M., Ilyas, Zailani, Sholatiana, Irvanto, F. A., 2014, Strategi dan Rencana Aksi
Provinsi. UNU Kalbar Press. Jl. KH. Achmad Dahlan No. 72 Pontianak.

Hartoko, A., Suryanti, Febrianti, D.A., 2013, Biomassa Karbon Vegetasi Mangrove Melalui Analisa Data Lapangan Dan Citra Satelit Geoeye Di Pulau Parang, Kepulauan. Journal Of Management of Aquatic Resources. 2 (2) : 9-18.

Imiliyana, A., Muryono, M., Purnobasuki, H., 2014, Estimasi Stok Karbon Pada Tegakan Pohon Rhizophora stylosa di Pantai Camplong, Sampang-Madura. Institut Teknologi Sepuluh Nopember.

Khairijon, Fatonah, S., Rianti, A. P., 2013, Profil Biomassa dan Kerapatan Vegetasi Tegakan Hutan Mangrove di Marine Station Kecamatan Dumai Barat, Riau. Prosiding Semirata FMIPA Universitas Lampung.

Keputusan Menteri Negara Lingkungan Hidup No 201 Tahun 2004. 2004. Tentang Kriteria Baku dan Pedoman Kerusakan Mangrove. Menteri Negara Lingkungan Hidup. Jakarta

Mandari, D.Z., Gunawan, H., Isda, M.N., 2016, Penaksiran Biomassa dan Karbon Tersimpan Pada Ekosistem Hutan Mangrove di Kawasan Bandar Bakau Dumai. Jurnal Riau Biologi. 1 (3): 17-23.

Mansur, I., Tuheteru, D.F., 2010, Kayu Jabon. Jakarta: Penebar Swadaya.

Manuri, S., Putra, C.A.S., Saputra, A.D, 2011, Teknik Pendugaan Cadangan Karbon Hutan. Merang redd Pilot Project-German 
International Cooperation (mrppgiz). Palembang.

Noor, Y.R., Khazali, M., Suryadiputra, I.N.N., 2006, Panduan Pengenalan Mangrove di Indonesia. Wetlands International Indonesia Programme. Bogor.

Suryandari, P., Astiani, D., Dewantara, I., 2019, Pendugaan Karbon Tersimpan Pada Tegakan Di Kawasan Arboretum Sylva Universitas Tanjungpura. Jurnal Hutan Lestari. 7 (1): 114 - 122.
Suryono, A., 2013, Sukses Usaha Pembibitan Mangrove Sang Penyelamat Pulau. Penerbit Pustaka Baru Bantul. Yogyakarta.

Wiarta, R., Astiani, D., Indrayani, Y., Mulia, F., 2017, Pendugaan Jumlah Karbon Tersimpan Pada Tegakan Jenis Bakau (Rhizopora apiculata BL) di IUPHHK PT. Bina Ovivipari Semesta Kabupaten Kubu Raya. Jurnal Hutan Lestari. 5 (2) : 356-364. 